\title{
Seasonal changes of benthic communities in a temporary stream of Ibiza (Balearic Islands)
}

\author{
Liliana García *, Cristina Delgado and Isabel Pardo \\ Departamento de Ecología y Biología Animal, Universidad de Vigo, E-36330 Vigo, España \\ *Corresponding author: lilizar@uvigo.es
}

Received: 17/1/08 Accepted: 17/6/08

\begin{abstract}
Seasonal changes in benthic communities in a temporary stream of Ibiza (Balearic Islands)

Seasonal changes in benthic communities (diatoms and invertebrates) in a temporary stream of the Ibiza island (Balearic Islands, Spain) were studied. The physico-chemical parameters, diatom quality indices and some invertebrate metrics were used to describe and identify the observed temporal changes in benthic communities. A total of 43 diatom taxa and 51 invertebrate taxa were identified. Only 4 diatom species appeared in all the samples: Achnanthidium minutissimum, Diploneis oblongella, Navicula veneta and Nitzschia inconspicua. The invertebrate community was dominated by the orders Diptera, Oligochaeta and Gastropoda along the sampling period. Changes in the physico-chemical parameters of the water and hydrological events determined the structure of the benthic communities in this temporary stream.
\end{abstract}

Key words: Diatoms, Ibiza, invertebrates, Mediterranean island, temporary streams.

\section{RESUMEN}

\section{Cambios estacionales de las comunidades bentónicas en un río temporal de Ibiza (Islas Baleares)}

Se han estudiado los cambios estacionales de las comunidades bentónicas (diatomeas e invertebrados) en un arroyo temporal de la isla de Ibiza (Islas Baleares, España). Los parámetros físico-químicos, índices diatomológicos de calidad y algunos métricos de invertebrados se han utilizado para describir e identificar los cambios temporales que se observan en las comunidades bentónicas. Se han identificado un total de 43 taxones de diatomeas y 51 taxones de invertebrados. Únicamente 4 especies aparecen en todas las muestras: Achnanthidium minutissimum, Diploneis oblongella, Navicula veneta y Nitzschia inconspicua. La comunidad de invertebrados estuvo dominada por los órdenes Diptera, Oligochaeta y Gastropoda a lo largo del período de muestreo. Los cambios en los parámetros físico-químicos del agua y los eventos hidrológicos determinaron la estructura de la comunidad bentónica en este río temporal.

Palabras clave: Diatomeas, Ibiza, invertebrados, isla mediterránea, ríos temporales.

\section{INTRODUCTION}

The Mediterranean climate of the Balearic Islands is characterized by irregular precipitations throughout the year. This includes heavy rains that generally take place during the autumn and spring months with the driest conditions prevailing in the summer (Pardo \& Álvarez, 2007), when temperature and light intensity are higher. In the Mediterranean streams as well as in other temporary systems, the differences in rainfall induce a periodically and predictable seasonal sequence of floods and droughts (Towns, 1985; Sabater \& Armengol, 1986; Resh et al., 1988; Poff, 1992; Flecker \& Feifarek, 1994; Romaní \& Sabater, 1997; Gasith \& Resh, 1999; Bonada et al., 
2000; Lake, 2000; Bravo et al., 2001; Lake, 2003; Morais et al., 2004). These involve changes in the physico-chemical parameters and on the community structure because of the disrupting processes (Gasith \& Resh, 1999; Lake, 2000).

The composition of benthic algal communities can be explained by the variations in the mineral content of the water (Sabater \& Sabater, 1988; Sabater, 1989) and in response to the annual variation in the magnitude of temperature, light and herbivorism (Álvarez \& Pardo, 2006), whereas invertebrate assemblages seem to be mainly influenced by the temporal and spatial variations in resources (Poff \& Ward, 1989). Other aspects, such as geomorphological factors (Stout, 1981, 1982), substratum size (Death, 1996) and riparian vegetation could influence (Sabater et al., 1998) on the benthic communities.

In the last twenty years, several studies developed in the Balearic Islands have related water chemistry to algal communities (Moyà et al., 1991; Moyà et al., 1993; Llobera \& Ferriol, 1994) and invertebrate assemblages (García
Avilés, 1990). Even more integrative studies have focused on the stream mentioned above (abiotic and biotic components) (Álvarez \& Pardo, 2005; Álvarez \& Pardo, 2006; Pardo \& Álvarez, 2006) and carried out on the island of Majorca, while the island of Ibiza has received much less attention (Margalef, 1951).

The objective of this study was to analyse the existing seasonal changes in the composition and abundance of benthic diatoms and invertebrates in a temporary stream of the Ibiza island, as well as to identify the influence of environmental factors in such changes.

\section{MATERIAL AND METHODS}

\section{Study area}

The island of Ibiza is located in the western part of the Mediterranean Sea (Fig. 1) having an area of $570 \mathrm{~km}^{2}$. It is the warmest island of the Balearic archipelago, with a semiarid climate. The ave-

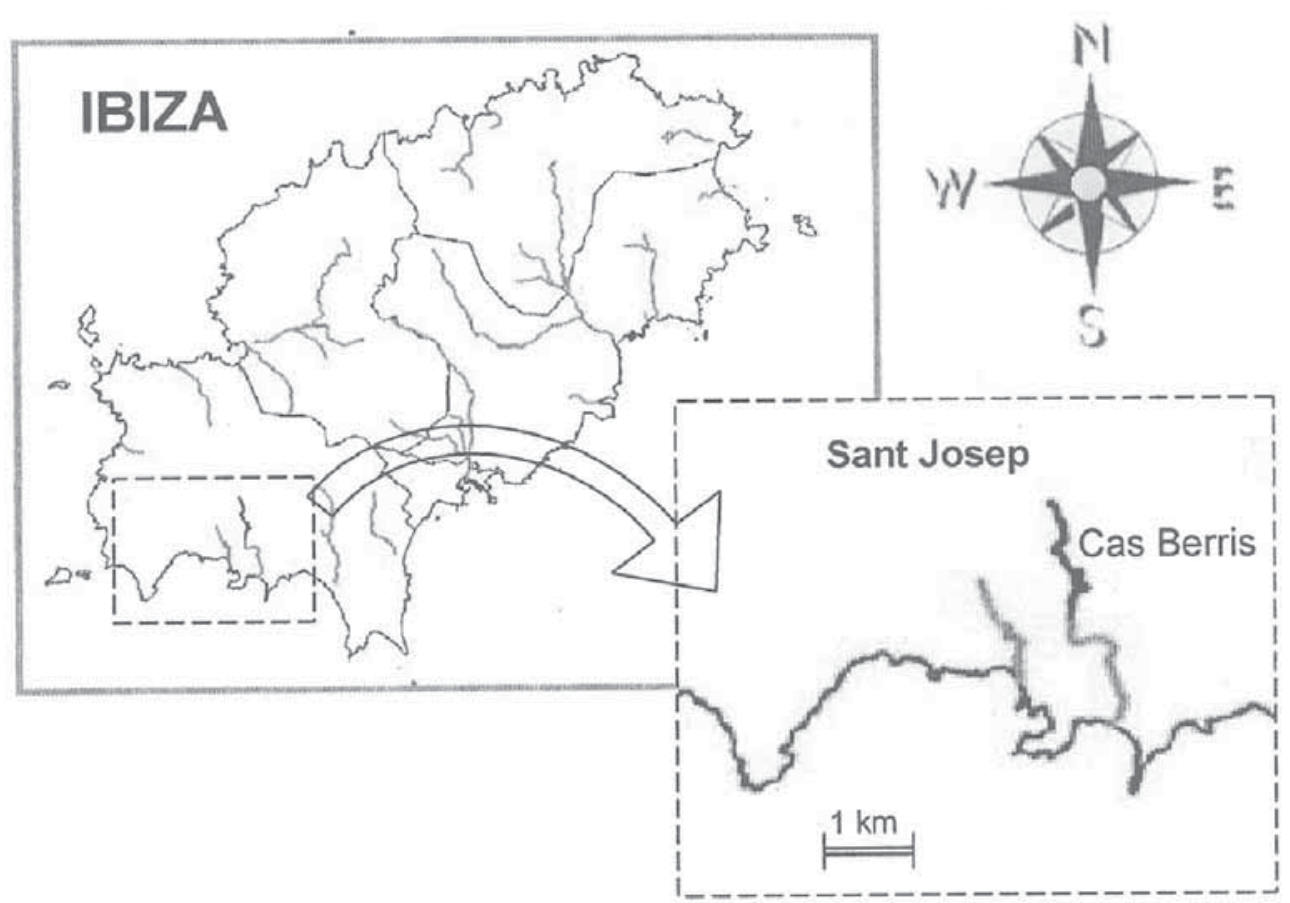

Figure 1. The Cas Berris stream and location of the sampling site. Torrente de Cas Berris y localización de la estación de muestreo. 
rage temperature ranges between 16 to $19.6^{\circ} \mathrm{C}$, the humidity varies between $15-95 \%$ and the precipitation average is low, with a monthly annual ranging from 3.4 to $116.6 \mathrm{~mm}$ during the study year. Geologically, the island is calcareous (limestone and conglomerates) and topographically has two small mountain ranges. These run in a SE-NE direction where the highest mountain is Sa Talasa Puig (486.7 $\mathrm{m}$ a.s.1.). The local geomorphology may play a major role in the hydrology dynamics and the fluvial system in the Sant Josep basin (SW of the island), which has several temporary streams of reduced length.

One of the few temporary streams of the island with a significant water length period, is the Cas Berris stream (UTM 352342 4308124) located close to the town of Sant Josep. Its watershed area is $18.4 \mathrm{~km}^{2}$ and the altitude is approximately $100 \mathrm{~m}$ a.s.1. Calcite-dolomite bedrock covers most of the Cas Berris stream bed which is dominated by accumulations of sand, lime, stones and boulders along the stream. Our area is characterised by typical rural land use and the vegetation is dominated by Pinus halepensis, Arundo donax, tall herbs and shrubs.

\section{Sampling, water chemistry and hydromorphological characterisation}

Samples were taken over the period of a water cycle: November (22/11/2005), March (04/03/2006) and May (14/05/2006). Sampling included a collection of biotic communities (epilithic diatoms and benthic invertebrates) and abiotic features in each data sampling. Field data sheets were completed with different aspects of the riparian adjacent areas, land uses and human impacts.

We selected a $100 \mathrm{~m}$ stretch, where water flowed over the sampling period for approximately 7 months. Rainfall data was registered from a meteorological station (83730 (LEIB), Es Codola) and accumulated for 15 days before the date of every sampling. The values ranged between $73.10 \mathrm{~mm}$ in November to $36.10 \mathrm{~mm}$ in March and $17.30 \mathrm{~mm}$ in May. The stream width was $0.7 \mathrm{~m}$ and the maximum depth was $15 \mathrm{~cm} \mathrm{du}-$ ring the studied period. Water samples for chemical analysis were collected from running water and environmental factors such as temperature, $\mathrm{pH}$, dissolved oxygen, electric conductivity of the water, and water flow were measured in situ with portable instruments calibrated in the field. The temperature and the oxygen were measured with an oxymeter "WTW 197", the water conductivity was measured at $25^{\circ} \mathrm{C}$ with an Orion Model 115, the $\mathrm{pH}$ with a Termo Orion $290+$ and the water flow was measured three times with a current meter Probe in one transect of the stream. Standard methods for chemical water analysis were carried out according to APHA protocols (APHA, 1989) and comprised the following nutrients and ions: calcium $\left(\mathrm{Ca}^{2+}\right)$, magnesium $\left(\mathrm{Mg}^{2+}\right)$, potassium $\left(\mathrm{K}^{+}\right)$, sodium $\left(\mathrm{Na}^{+}\right)$, nitrates $\left(\mathrm{NO}_{3}^{-}\right)$, silica $\left(\mathrm{SiO}_{2}\right)$, phosphates $\left(\mathrm{PO}_{4}^{3-}\right)$ and sulphates $\left(\mathrm{SO}_{4}^{2-}\right)$. Benthic samples of chlorophyll $a(\mathrm{Chl} a)$ were taken from stones, stored on ice and frozen until processed. In the laboratory, these samples were filtered using the glass-fibber filters. Later, they were ground in $90 \%$ acetone. Chlorophyll concentration was determined by extraction during $48 \mathrm{~h}$ at $4^{\circ} \mathrm{C}$ in the dark. After extraction, chlorophyll $a$ was measured spectrophotometrically (Hitachi Model U-2001 UV/Visible Spectrophotometer) and corrected for degradation products using the equations given by Lorenzen (1967).

Hydromorphological features (taken, in the field, along the stretch and 500 meters upstream) were registered in the CARAVAGGIO software in May 2006. This software is a version of the River Habitat Survey (RHS) used to evaluate the hydromorphological quality (Buffagni et al., 2002, 2004) being also able to derive information on its local and hydrologic character. According to the results, our stream is composed by diverse habitats (Habitat Quality Assessment, HQA = 37), the water flow is slow and varies with riffles and pools (Lentic-lotic River Descriptor, LRD $=45$ ) and the whole reach is gently modified by the anthropogenic effect (Habitat Modification Score, HMS = 26). The riparian vegetation cover is mainly due to the existence of reeds, shrubs, grasses $(50 \%)$ and conifers $(20 \%)$ occupying the upper part of the basin. Harvest, due to cleaning activities, is performed every year in the banks to prevent debris dam accumulation along the stream. 


\section{Community assemblage}

Epilithic diatoms were collected from natural substrates (stones) following the European norms (Kelly et al., 1998; European Committee for Standardization, 2004; AFNOR, 2003). The samples were preserved with formaldehyde solution $(4 \%)$ immediately after collection. Afterwards, samples were treated to obtain a suspension with the clean frustules. Organic matter was eliminated with hydrogen peroxide and diluted $\mathrm{HCl}$ was added to remove the calcium carbonate (Renberg, 1990). Finally, after distilled water rinsing, permanent slides were mounted with Naphrax@. Diatoms were identified to species level using light microscopes Olympus BX40; at least 400 valves were identified and counted from each slide (Prygiel \& Coste, 1993). The diatoms were identified at the lowest taxonomical level according to the following authors: Coste (1982); Krammer \& Lange-Bertalot (1985, 1986, 1988, 1991a, 1991b, 2000); Krammer (1997a, 1997b, 2002); Lange-Bertalot (1993, 1999, 2001); Lange-Bertalot \& Krammer (1989); Lange-Bertalot \& Moser (1994).

Diatom abundance data were introduced in the Omnidia v.4.2 software (Lecointe et al., 1993) that calculates different indices, in order to analyse seasonal changes in water quality. Each index differs in the number of used species and the sensitivity values of the taxa that have been judged after compiling available literature information (Prygiel \& Coste, 1993; Van Dam et al., 1994). We studied four indices: Specific Pollution Sensitivity Index: IPS (Coste, 1982); Biologic Diatom Index: IBD (Lenoir \& Coste, 1996); Trophic Diatom Index: TDI (Kelly \& Witton, 1995) and European Index: CEE (Descy \& Coste, 1989). We selected these indices due to their widespread use in Spain, Portugal and other European countries. Final values of these indices were transformed in water, quality estimates ranging between 1 (worse quality) and 20 (best quality). After adjustment by linear relation, five quality categories, established by the WFD (European Union, 2000), can be defined by the values of these indices: high (>17), good (13-17), moderate $(9-13)$, poor $(5-9)$ and bad $(<5)$. The Shannon-
Wiener Diversity Index was calculated as the sum over all the species in a sample.

Invertebrates were collected following a multi-habitat procedure (adapted from EPA, Barbour et al., 1999) in which, 20 sampling units (with a kicknet of $500 \mu \mathrm{m}$ ), that correspond to an area of $2.5 \mathrm{~m}^{2}$, were sampled. Samples were preserved in plastic bags in the field with ethanol $(70 \%)$, carried to the laboratory and stored until their treatment. Then, samples were washed under tap water in three different fractions ( $5 \mathrm{~mm}, 0.5 \mathrm{~mm}$ and $0.1 \mathrm{~mm}$ ) and specimens were counted and identified under 40X magnification (Olympus U-TV1X) up to the lowest possible identification level (except for some Diptera, Oligochaeta and Hydrachnidia). Sub-sampling was made, when necessary, to obtain a representative fraction of the total community (Wrona $e t$ $a l ., 1982)$. Assignment of taxa to functional feeding groups followed the classification of Cummins and Merrit (1996) and Álvarez (2004). The composition and abundance data of the invertebrate community were introduced in the ASTERICS program (software v.3.01) to calculate several indices (i.e. richness, Shannon-Wiener Index, EPT taxa) which were used to examine changes in invertebrate community structure.

Table 1. Seasonal values of the physico-chemical parameters measured in Cas Berris stream. Valores estacionales de los parámetros físico-químicos medidos en el torrente de Cas Berris.

\begin{tabular}{lrrr}
\hline $\begin{array}{l}\text { Physico-chemical } \\
\text { parameters }\end{array}$ & $22 / 11 / 2005$ & $04 / 03 / 2006$ & $14 / 05 / 2006$ \\
\hline Water Temperature $\left({ }^{\circ} \mathrm{C}\right)$ & 15.9 & 15.9 & 19.6 \\
Dissolved oxygen $\left(\mathrm{mg} \mathrm{L}^{-1}\right)$ & 9.2 & 9.2 & 8.4 \\
$\mathrm{pH}$ & 7.9 & 7.6 & 7.9 \\
$\mathrm{Conductivity}\left(\mu \mathrm{S} \mathrm{cm}^{-1}\right)$ & 2375.0 & 1875.0 & 2179.0 \\
Water flow $\left(\mathrm{L} \mathrm{s}^{-1}\right)$ & 1.1 & 18.6 & 1.17 \\
$\mathrm{Chl}\left(\mathrm{mg} \mathrm{cm}^{2} \mathrm{~L}^{-1}\right)$ & 0.16 & 5.30 & 2.21 \\
$\mathrm{Ca}^{2+}\left(\mathrm{mg} \mathrm{L}^{-1}\right)$ & 199.40 & 117.10 & 118.40 \\
$\mathrm{~K}^{+}\left(\mathrm{mg} \mathrm{L}^{-1}\right)$ & 5.17 & 5.19 & 3.28 \\
$\mathrm{Mg}^{2+}\left(\mathrm{mg} \mathrm{L}^{-1}\right)$ & 84.79 & 39.33 & 43.43 \\
$\mathrm{Na}^{+}\left(\mathrm{mg} \mathrm{L}^{-1}\right)$ & 301.60 & 159.90 & 160.90 \\
$\mathrm{SO}_{4}^{2-}\left(\mathrm{mg} \mathrm{L}^{-1}\right)$ & 185.52 & 133.95 & 130.33 \\
$\mathrm{PO}_{4}^{3-}\left(\mathrm{mg} \mathrm{L}^{-1}\right)$ & 0.32 & 0.04 & 0.12 \\
$\mathrm{NO}_{3}^{-}\left(\mathrm{mg} \mathrm{L}^{-1}\right)$ & 16.33 & 19.33 & 25.77 \\
${\mathrm{~S}\left(\mathrm{mg} \mathrm{L}^{-1}\right)}_{\mathrm{SiO}_{2}\left(\mathrm{mg} \mathrm{L}^{-1}\right)}$ & 6.19 & 24.77 & 41.93 \\
\hline
\end{tabular}


Table 2. List and abundance percentage of diatoms taxa identified in the Cas Berris stream during the sampling period. One asterisk: new taxa for Ibiza island and two asterisk new taxa for Balearic diatom flora. Listado y porcentaje de abundancia de las diatomeas identificadas en el torrente de Cas Berris durante el periodo de muestreo. Un asterisco: las nuevas aportaciones a la flora de la isla de Ibiza y dos asteriscos las nuevas aportaciones a la flora de las Islas Baleares.

\begin{tabular}{|c|c|c|c|c|}
\hline Code & Taxa & $22 / 11 / 2005$ & $04 / 03 / 2006$ & $14 / 05 / 2006$ \\
\hline ATHE & **Achnanthidium thermale Rabenhorst & 0.00 & 9.63 & 12.72 \\
\hline ADMI & Achnanthidium minutissimum (Kützing) Czarnecki & 15.67 & 72.25 & 55.22 \\
\hline ASP1 & Achnanthidium sp. & 0.00 & 1.83 & 1.53 \\
\hline AMMO & **Amphora montana Krasske & 0.00 & 0.00 & 0.25 \\
\hline ANOR & *Amphora normanii Rabenhorst & 2.21 & 0.00 & 0.00 \\
\hline APED & Amphora pediculus (Kützing) Grunow & 0.22 & 0.00 & 0.25 \\
\hline AMPS & Amphora species & 0.00 & 0.00 & 0.25 \\
\hline BVIT & *Brachysira vitrea (Grunow) Ross in Hartley & 0.00 & 0.00 & 1.53 \\
\hline CPUL & Caloneis pulchra Messikommer & 0.22 & 0.00 & 0.00 \\
\hline CALS & Caloneis species & 0.44 & 0.00 & 0.00 \\
\hline CMIC & Cymbella microcephala Grunow & 0.00 & 0.69 & 4.83 \\
\hline DKUE & **Denticula kuetzingii Grunow var. küetzingii & 0.44 & 0.00 & 0.00 \\
\hline DSUB & **Denticula subtilis Grunow & 0.66 & 0.00 & 0.00 \\
\hline DTEN & Denticula tenuis Kützing & 0.00 & 0.00 & 0.00 \\
\hline DOBL & Diploneis oblonguella (Naegelii) Cleve-Euler & 1.99 & 1.15 & 2.29 \\
\hline DOVA & Diploneis ovalis (Hilse) Cleve & 0.22 & 0.00 & 0.51 \\
\hline FCRP & **Fragilaria capucina Desm. var. rumpens & 0.22 & 0.00 & 0.51 \\
\hline FRAS & Fragilaria species & 0.00 & 0.00 & 1.78 \\
\hline FUAC & Fragilaria ulna var. acus (Kützing) Lange-Bertalot & 0.00 & 0.00 & 0.25 \\
\hline GCLA & **Gomphonema clavatum Ehrenberg & 0.00 & 1.61 & 0.00 \\
\hline GOMP & **Gomphonema dichotomum Kützing & 0.00 & 2.52 & 13.23 \\
\hline GGRA & *Gomphonema gracile Ehrenberg & 0.22 & 0.00 & 0.00 \\
\hline GPUM & **Gomphonema pumilum (Grunow) Reichar. \& Lange-Bert. & 1.10 & 0.23 & 0.00 \\
\hline GROS & *Gomphonema rosenstockianum Lange-Bert. \& Reicha. & 0.00 & 0.46 & 0.00 \\
\hline NSIT & *Grunowia tabellaria (Grunow) Rabenhorst & 0.00 & 0.23 & 0.00 \\
\hline LMTP & **Luticola muticopsis (Van Heurck) D.G. Mann & 0.22 & 0.00 & 0.00 \\
\hline NCIN & *Navicula cincta (Ehrenberg) Ralfs in Pritchard & 9.93 & 0.23 & 0.00 \\
\hline NCTO & **Navicula cryptotenelloides Lange-Bertalot & 0.00 & 0.00 & 1.02 \\
\hline NCRY & Navicula crytocephala Kützing & 0.44 & 0.00 & 0.00 \\
\hline NAVI & NAVICULA J.B.M. Bory de Sant Vincent & 0.22 & 0.00 & 0.51 \\
\hline NLAN & Navicula lanceolata (Agardh) Ehrenberg & 0.00 & 0.00 & 0.25 \\
\hline NVEN & **Navicula veneta Kützing & 16.11 & 0.23 & 1.78 \\
\hline NIFR & **Nitzschia frustulum (Kützing) Grunow var. frustulum & 1.99 & 0.23 & 0.00 \\
\hline NINC & **Nitzschia inconspicua Grunow & 41.06 & 7.80 & 0.51 \\
\hline NREC & **Nitzschia recta Hantzsch in Rabenhorst & 0.44 & 0.00 & 0.00 \\
\hline NIVI & *Nitzschia vitrea Norman & 1.77 & 0.00 & 0.00 \\
\hline PSCA & **Pinnularia subcapitata Gregory & 0.22 & 0.00 & 0.00 \\
\hline PLFR & **Planothidium frequent Lange-Bert.) Round \& Bukh. & 0.00 & 0.46 & 0.00 \\
\hline SSTM & **Sellaphora stroemii (Hustedt) Mann & 0.00 & 0.00 & 0.76 \\
\hline SOVI & Surirella ovalis Brébisson & 0.22 & 0.00 & 0.00 \\
\hline TAPI & Tryblionella apiculata Gregory & 0.22 & 0.00 & 0.00 \\
\hline TDEB & **Tryblionella debilis Arnott ex O’Meara & 3.53 & 0.00 & 0.00 \\
\hline UBIC & *Ulnaria biceps (F.T. Kützing) Compère & 0.00 & 0.46 & 9.41 \\
\hline
\end{tabular}

A hierarchical clustering and an ordination by non-metric multidimensional scaling (MDS) was made with the abundance data from both biotic communities. These analyses were carried out with the software PRIMER 6, previous $\log (x+1)$ transformation of the abundances.

\section{RESULTS}

\section{Physico-chemical and hydromorphological}

The water chemistry and hydromorphological characteristics of the stream channel were as- 
Table 3. Quality and diversity indices of benthic diatom community of Cas Berris stream in each sample. Indices de calidad $y$ diversidad de la comunidad de diatomeas bentónicas del torrente de Cas Berris en cada muestra.

\begin{tabular}{lccc}
\hline Diatom Indices & $22 / 11 / 2005$ & $04 / 03 / 2006$ & $14 / 05 / 2006$ \\
\hline IPS & 9.2 & 17.3 & 15.3 \\
IBD & 6.9 & 14.2 & 14.3 \\
TDI & 8.0 & 16.6 & 15.4 \\
CEE & 9.2 & 15.6 & 16.6 \\
Shannon-Weaver Diversity & 2.8 & 1.6 & 2.6 \\
\hline
\end{tabular}

sessed during the three different seasons used to characterise the Cas Berris torrent (Table 1). Water temperature ranged annually between $15.95-19.60^{\circ} \mathrm{C}$, indicating little variation during the year, with the highest value in May. Oxygen concentration did not vary too much between seasons (8.37-9.24 $\mathrm{mg} \mathrm{L}^{-1}$ ). The $\mathrm{pH}$ ranged between 7.62 and 7.99 during the study period. Water conductivity was considered as a representative variable of the total ionic strength; it was high in all seasons but it had the highest value in November (2 $375 \mu \mathrm{S} \mathrm{cm}^{-1}$ ). Nitrate values were also high between $16.33-25.77 \mathrm{mg} \mathrm{L}^{-1}$, which is related to the groundwater input of the nutrients probably from agricultural adjacent areas. $\mathrm{Ca}^{2+}$ is dominant in Balearic running waters because of the dissolution of the calcareous substrata and it ranged between 117.1-199.4 $\mathrm{mg} \mathrm{L}^{-1}$. The chl $a$ and the silica had the lowest values in November.

\section{Diatoms}

A total of 43 taxa belonging to 19 genera, were identified over the year (Table 2). Of these taxa, 26 were first cited in the island of Ibiza and 18 of them in the Balearic Islands, after revision of the latest literature updated by Aboal et al. (2003). Only four species appeared in all seasons: Achnanthidium minutissimum, with percentages over $15 \%$ in all samples, Diploneis oblongella, Navicula veneta and Nitzschia inconspicua. The diatom community in Cas Berris stream was dominated in November by Nitzschia inconspicua (41.06\%) together with Achnanthidium minutissimum (15.67\%) and Navicula veneta (16.11\%). Taxa as Amphora normanii (2.21\%), Navicula cincta $(9.93 \%)$ and Tryblionella debilis $(3.53 \%)$ also characterised the community in this season, but in lower percentages. In March, Achnanthidium minutissimum was the most abundant species $(72.25 \%)$ with a strong decrease of Nitzschia inconspicua $(7.8 \%)$ and the apparition of Achnanthidium thermale (9.63\%), and of Gomphonema dichotomum (2.52\%). The percentages of Achnanthidium thermale (12.72\%), Gomphonema dichotomum (13.23\%) and Ulnaria biceps $(9.41 \%)$ increased towards May, slightly reducing the relative Achnanthidium minutissimum abundance $(55.22 \%)$.

\section{Diatom quality indices}

The values of the diatom indices: IPS, IBD, CEE, TDI and the Shannon-Wiener diversity index calculated with the software Omnidia v.4.2 showed that the values of the different quality indices greatly varied between the three sampling periods, with values ranging from 6.9 to 17.3.

We observed that the values of all indices are lowest in November (Table 3), but in contrast, the diversity is the highest, with a value of 2.77. In March, the IPS and TDI had the highest values but the diversity was the lowest (Table 3).

\section{Invertebrates}

A total of 51 invertebrate taxa were recorded in the Cas Berris torrent, although those that contributed less than $1 \%$ to the total abundance were eliminated, resulting in a total of 21 taxa (Table 4). The invertebrate community in the stream over the sampling period was dominated by Diptera (69.8\% from the total, distributed between 5 taxa), Gastropoda (9.74\% distributed between 4 taxa) and Oligochaeta $(8.6 \%)$. The rest of the community was composed by Ephemeroptera, Ostracoda, Acari, Odonata, and Trichoptera taxa.

The invertebrate composition changed seasonally; Oligochaeta and Gastropoda were well represented during November, when the lowest benthic abundance occurred (Table 5). In March and May, the community was dominated by Diptera, mostly Chironomidae and species such as Cloeon dipterum, Hydroptila sp. and Oxyethira 
Table 4. List and percentage of total abundance of benthic invertebrates identified in the Cas Berris stream during the sampling period. The table only includes those taxa with a percentage higher than $1 \%$ of the total abundance. Listado y porcentaje de la abundancia total de los invertebrados bentónicos identificados en el torrente de Cas Berris durante el periodo de muestreo. La tabla sólo incluye aquellos taxones que presentaron un porcentaje superior al $1 \%$ de la abundancia total.

\begin{tabular}{|c|c|c|c|c|c|}
\hline ORDER & TAXANAME & Shortcode & $22 / 11 / 2005$ & $04 / 03 / 2006$ & $14 / 05 / 2006$ \\
\hline ACARI & Hydrachnidia Gen. sp. & HYDRGESP & 0.00 & 0.00 & 3.07 \\
\hline COLEOPTERA & Dryops sp.Lv. & DRYOPSSP & 0.09 & 1.18 & 0.05 \\
\hline \multirow[t]{6}{*}{ DIPTERA } & Ceratopogoninae Gen. sp. & CENAGEN & 0.09 & 4.42 & 0.00 \\
\hline & Muscidae Gen. sp. & MUSCGEN & 0.00 & 0.00 & 1.49 \\
\hline & Orthocladiinae Gen. sp. & ORTINAEG & 4.76 & 15.60 & 6.71 \\
\hline & Simulium sp.Lv. & SIMULISP & 0.00 & 19.03 & 0.19 \\
\hline & Tanypodinae Gen. sp. & TANNAEGE & 1.43 & 4.73 & 9.48 \\
\hline & Tanytarsini Gen. sp. & TANINIGE & 0.00 & 20.31 & 59.00 \\
\hline \multirow[t]{2}{*}{ EPHEMEROPTERA } & Caenis luctuosa & CAENLUCT & 1.28 & 0.91 & 2.05 \\
\hline & Cloeon dipterum & CLOEDIPT & 0.00 & 0.00 & 3.55 \\
\hline \multirow[t]{5}{*}{ GASTROPODA } & Gyraulus laevis & GYRALAEV & 6.90 & 0.59 & 0.00 \\
\hline & Gyraulus sp. & GYRASP & 0.00 & 0.00 & 1.49 \\
\hline & Lymnaea (Galba) truncatula & GALBTRUN & 5.56 & 14.71 & 0.00 \\
\hline & Physella acuta & PHYSACUT & 2.23 & 4.42 & 0.88 \\
\hline & Pseudamnicola spirata & PSEUSP & 1.90 & 0.00 & 0.00 \\
\hline NEMATODA & Nematoda Gen. sp. & NEMATOGE & 1.90 & 0.00 & 0.74 \\
\hline ODONATA & Libellulidae Gen. sp. & LIBEGEN & 0.00 & 0.00 & 1.20 \\
\hline OLIGOCHAETA & Enchytraeidae Gen. sp. & ENCHYGEN & 68.75 & 11.24 & 0.74 \\
\hline OSTRACODA & Ostracoda Gen. sp. & OSTRGEN & 1.90 & 1.18 & 3.77 \\
\hline \multirow[t]{2}{*}{ TRICHOPTERA } & Hydroptila sp. & HYTILASP & 0.00 & 0.00 & 1.07 \\
\hline & Oxyethira sp. & OXYESP & 0.00 & 0.00 & 1.95 \\
\hline
\end{tabular}

sp., which only appeared in May (Table 5). Caenis luctuosa was more abundant during May, in parallel with the highest values of EPT index. Taxa richness increased from November (22 taxa) to March (25 taxa) and May (31 taxa). Higher diversity $\left(H^{\prime}\right)$ was observed in March, although it was similar between seasons (Table 5).

Total collectors were the most important trophic group over the studied period, although the proportions changed between seasons (Table 5). Collector-gatherers were best represented in November while collector-filterers in March and May. Predators increased towards summer and scrapers were more important in other seasons. Shredders had the smallest representation $(3.08 \%)$ in the community.

The ordination analyses showed the distribution of the benthic species along the year. In the plot we can differentiate three groups of species with a $60 \%$ of similarity in their taxa composition (Fig. 2), representing the seasonal changes identified with the succession of the benthic communities (diatoms and invertebrates) from November to March and May.

\section{DISCUSSION}

Although the data analysed in this study was limited to one small temporary stream, the information supplied in this article adds to the current knowledge on the aquatic communities of the Balearic Islands, the hydromorphological and physico-chemical factors, and the benthic communities of the Ibiza Island.

Table 5. Seasonal values of some metrics calculated for the benthic invertebrate community of Cas Berris stream in each sample. Valores estacionales de algunos métricos calculados para la comunidad de invertebrados bentónicos del torrente de Cas Berris en cada muestra.

\begin{tabular}{lrrr}
\hline Indices & $22 / 11 / 2005$ & $04 / 03 / 2006$ & $14 / 05 / 2006$ \\
\hline Abundance & 3363 & 21760 & 34388 \\
Richness & 22 & 25 & 31 \\
Diversity (S-W Index) & 1.36 & 2.14 & 1.72 \\
EPT (\%) & 5.33 & 8.91 & 20.69 \\
\% Collectors (undetermined) & 1.94 & 1.18 & 3.80 \\
\% Collector-Filterers & 0.00 & 39.65 & 59.64 \\
\% Collector-Gatherers & 77.11 & 28.10 & 13.44 \\
\% Predators & 2.64 & 9.56 & 16.58 \\
\% Scrapers & 17.98 & 19.73 & 5.58 \\
\% Shredders & 0.33 & 1.78 & 0.97 \\
\hline
\end{tabular}




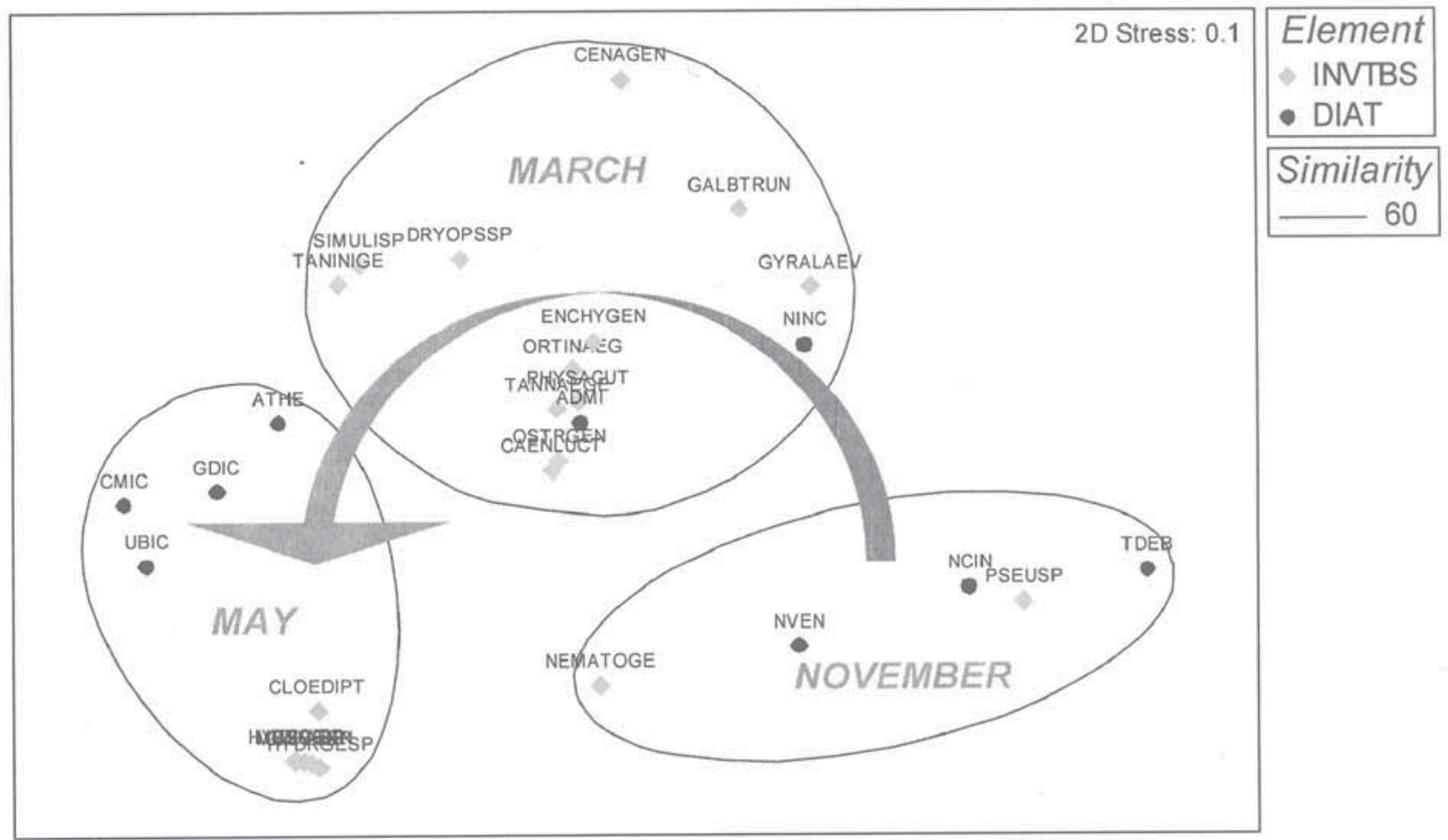

Figure 2. Multidimensional scaling of the biotic abundances (diatoms and invertebrates) represented in the Cas Berris stream. Escalamiento multidimensional de las abundancias de la biota (diatomeas e invertebrados) representadas en el torrente de Cas Berris.

There were major changes in the diatom composition in the Cas Berris stream along the year, related to small variations in the physico-chemical conditions and temporal succession. In November, the water chemistry was characterised with the highest values of $\mathrm{Ca}^{2+}, \mathrm{Na}^{+}, \mathrm{Mg}^{2+}, \mathrm{SO}_{4}^{2-}$, and $\mathrm{PO}_{4}^{3-}$ and the diatom community was characterised by a high abundance of Nitzschia inconspicua, that appeared together with Achnanthidium minutissimum, Navicula veneta, Navicula cincta, and Tryblionella debilis. Nitzschia inconspicua is abundant in waters of medium to high electrolytic conditions and tolerates a high organic loading. This species is tolerant to the pollution (Gomà, 2004), which confers low values to the quality indices in November, defined between the poor and moderate classes.

The values of some nutrients were reduced in March possibly due to the strong increase of discharge that could induce a high development of Achnanthidium minutissimum sensu lato which was the dominant taxa. This species is one of the most frequent diatoms occurring in freshwa- ter benthic samples (Krammer \& Lange-Bertalot, 1991), being considered an ubiquitous species (Van Dam et al., 1994) and a cosmopolitan pioneer in disturbed environments (Passy \& Bode, 2004). This species dominated the community in March together with the presence of Nitzschia inconspicua and Achnanthidium thermale, influencing the lowest values of diversity.

The species Achnanthidium thermale and its varieties is particularly abundant in the North of Africa. In Europe it is a frequent inhabitant of mineral and thermal sources (Hustedt, 1930, 1959; Lange-Bertalot \& Krammer, 1989; Krammer \& Lange-Bertalot, 1991) and alkaline waters with high conductivity and rich in $\mathrm{Ca}^{2+}, \mathrm{Na}^{+}, \mathrm{K}^{+}$and $\mathrm{SO}_{4}^{2-}$ (Krammer \& Lange-Bertalot, 1991; Coste $\&$ Ector, 2000). The presence of this species in Cas Berris stream is uncommon because it did not appear in the other Balearic Islands (Pardo et al., 2007), but it is possible that the high values of water temperature, conductivity, $\mathrm{Na}^{+}$and $\mathrm{Ca}^{2+}$ that exist in Cas Berris stream favoured its presence. Its abundance increased in May toge- 
ther with Ulnaria biceps and Gomphonema dichotomum; this season was characterised by having the highest $\mathrm{NO}_{3}^{-}$levels and water temperatures, due to the high temperatures. The abundance of A. minutissimum was reduced in May possibly because the community was in the process to stabilising, increasing the number of species and the diversity. The values of the indices IPS, TDI and CEE had similar values in March and May. Their values ranged between 15.3 and 17.3; only CEE had values lower than 15 , but according to them, the status of the water quality in Cas Berris stream was between good and high.

Particularly interesting are the 26 new diatom records found for the Ibiza flora and the 18 for the Balearic Islands; this great amount of new cited taxa can be explained by the lack of important taxonomical studies in the island. Several common taxa in the European flora have not be previously cited in Ibiza due to a lack of studies or because some of them are taxa recently described or separated from older complex species such as Brachysira vitrea, Grunowia tabellaria, Sellaphora stroemii and Tryblionella debilis. In the future, we expect to explore the existence of other new species after revision with electronic microscope, because, some species as Diploneis oblongella may vary towards: $D$. fontanella or D. separanda (Werum \& Lange-Bertalot, 2004) or in the case of Cymbella microcephala, can be different species of the genus Encyonopsis as: E. microcephala, E. minuta, E. krammerii or E. subminuta (Krammer, 1997b).

We have observed an increase in invertebrate taxa richness and a temporal replacement of species in the Cas Berris stream along the year, although in temporary systems, sudden increases or decreases in the flow can break the benthic succession and, consequently, may imply changes in benthic communities (Lake, 2003). The time elapsed after the resumption of water played an important role in the colonisation of invertebrates, as well as the permanence of the water in temporary systems (Álvarez \& Pardo, 2007) increasing the complexity in the richness of the community.

Aquatic invertebrates have adapted their life cycles in response to environmental factors such as temperature, food, habitat, photoperiod (Perán et al., 1999), and discharge (Flecker \& Feifarek, 1994; Lake, 2003). The invertebrate community in the studied stream changed seasonally. As expected after the autumn rainfall, the lowest abundance occurred in November. Posterior increases in periphyton biomass (measured as chlorophyll a) may have promoted the colonisation by scrapers (molluscs). The availability of food may determine the existence of the invertebrates along the water period. In this stream, dominant functional feeding groups are collectors indicating a dominance of fine organic matter along the year, followed in representation by scrapers revealing the importance of periphyton as an alternative food source in autumn and spring for these systems.

Oligochaeta and Diptera are characteristic taxa in spring habitats of Majorca (Álvarez, 2004) and they appear in high percentages in our stream; this may be due to their capacity to resist and recover from extreme conditions (Lake, 2003). Cloeon dipterum is a common species in this study and in other temporary streams of the Balearic Islands (Pardo et al., 2007) because its preference to inhabit in pools and streams close to being dry (Belfiore, 1983, Studemann et al., 1992). We also note the presence of other common inhabitants of temporary streams, like Caenis luctuosa with flexible life cycles and highly tolerant to changing conditions (Perán et al., 1999).

We observed, for example, that some Gastropoda (Physella acuta and Lymnaea (Galba) truncatula) had a negative relation with discharge (Table 1), indicating that their abundance is reduced in May. Both species are cosmopolitan and well-represented in Ibiza and in other temporary streams of the Balearic Islands (Pardo et al., 2007). Other taxa such as Libellulidae sp., Cloeon dipterum, Hydroptila sp. and Oxyethira sp have an opposite response, appearing only at the beginning of the dry period and increasing as a consequence the EPT index. In March and May the community was dominated by opportunistic taxa, mostly Chironomidae which are species well adapted with a short life cycle, and resistant to changes in water conditions (Williams, 1996, Langton \& Casas, 1999). 
In general, temporary streams are systems with unique characteristic. In these systems the important and predictable flow changes are the main disturbance determining biotic communities, where sudden changes in water chemistry and water flow may determine the biotic community; although there are several abiotic factors that can influence diatom communities (Leira \& Sabater, 2005) and invertebrate communities (Perán et al., 1999; Lake, 2003). It seems that the succession of the diatom community is driven by flow thus influencing physicochemical local changes and nutrient contents. Meanwhile, the invertebrate community seems to be more influenced by the seasonal constraints in water availability and related length of the water period influencing life cycles completion as well as other environmental factors such as temperature and food resources.

\section{ACKNOWLEDGEMENTS}

This paper complements some of the results obtained in the project relating to the application of the Water Framework Directive in the Balearic Islands. The financial support for this study has been facilitated by the Balear Government (Spain) and this also included the support of the University of Vigo (Spain). We are grateful to Mar Dominguez for the help in the chemical analysis of the water.

\section{REFERENCES}

ABOAL, M., M. ÁLVAREZ-COBELAS, J. CAMBRA \& L. ECTOR. 2003. Floristic list of the non marine diatoms (Bacillariophyceae) of Iberian Peninsula, Balearic Islands and Canary Islands. Diatom Monographs, vol. 4. Scientific Books Koenigstein (Germany). 639 pp.

AFNOR. 2003. Norme française NF EN 13946. Qualité de l'eau -Guide pour l'échantillonnage en routine et le prétraitement des diatomées benthiques de rivières. Association Française de Normalisation, $18 \mathrm{pp}$.
ÁLVAREZ, M. 2004. Ecología de los ríos temporales de la isla de Mallorca. Ph.D. Thesis. University of Vigo. 186 pp.

ÁLVAREZ, M. \& I. PARDO. 2005. Life history and production of Agapetus quadratus (Trichoptera: Glossosomatidae) in a temporary spring-fed stream. Freshwat. Biol., 50: 930-943.

ÁLVAREZ, M. \& I. PARDO. 2006. Factors controlling epilithon biomass in a temporary, karstic stream: the interaction between substratum and grazing. J. North Am. Benthol. Soc., 26(2): 207220.

ÁLVAREZ, M. \& I. PARDO. 2007. Do temporary streams of Mediterranean islands have a distinct macroinvertebrate community? The case of Majorca. Fundamental and Applied Limnology. Archiv für Hydrobiology, 168(1): 55-70.

APHA. 1989. Standard methods for the examination of the water and wastewater. $18^{\text {th }} \mathrm{Ed}$. American Public Health Association. Washington, D.C. 874 pp.

BARBOUR, M. T., J. GERRITSEN, B. D. SNYDER, \& J. B. STRIBLING, 1999. Rapid Bioassessment Protocols for Use in Streams and Wadeable Rivers: Periphyton, Benthic Macroinvertebrates and Fish, Second edition. EPA 841-B-99-002. U.S. Environmental Protection Agency; Office of Water; Washington, D. C. 339 pp.

BELFIORE, C. 1983. Guide per il riconoscimento delle specie animali delle acque interne italiane 24.Efemerotteri. Consiglio Nazionale delle Ricerche. 113 pp.

BONADA, N., M. RIERADEVALL y N. PRAT. 2000. Temporalidad y contaminación como claves para interpretar la biodiversidad de macroinvertebrados en un arroyo mediterráneo (Riera de Sant Cugat, Barcelona). Limnetica, 18: 81-90.

BRAVO, R., M. C. SORIGUER, N. VILLAR \& J. A. HERNANDO. 2001. The dynamics of fish populations in the Palancar stream, a small tributary of the river Guadalquivir, Spain. Acta Oecologica, 22: 920.

BUFFAGNI A., S. ERBA, R. BALESTRINI, M. CAZZOLA, J. L. KEMP, R. PAGNOTTA, R. ALBER, E. BIELLI, C. BELFIORE \& D. HERING, 2002. Definizione della qualità ecologica nei fiumi europei sulla base dei macroinvertebrati bentonici: il Progetto EUAQEM. Acta Biologica, 78(1): 181-193.

BUFFAGNI A., S. ERBA, D. ARMANINI, D. DE MARTINI \& S. SOMARÉ. 2004. Aspetti idromorfologici e carattere lenticolotico dei fiumi medi- 
terranei: River Habitat Survey e descrittore LRD. In 'Classificazione ecologica e carattere lenticolotico in fiumi mediterranei'. Quaderni Istituto di Recerca sulle Acque, Roma 122: 41-63.

COSTE, M. 1982. Étude des méthodes biologiques d'appréciation quantitative de la qualité des eaux. Rapport Q.E. Lyon, Agence de l'Eau RhôneMéditérannée-Corse-Cemagref, Lyon, 218 pp.

COSTE, M. et L. ECTOR. 2000. Diatomées invasives exotiques ou rares en France: principales observations effectuées au cours des derniéres décennies. Systematics Geography of Plants, 70: 373-400.

CUMMINS, W. K. \& R. W. MERRITT, 1996. Ecology and Distribution of Aquatic Insects. In: Aquatic Insects of North American, $3^{\text {rd }}$ ed. K. W. Cummins \& R. W. Merritt (eds.): 74-86. Dubuque, Iowa, USA.

DEATH, R. G. 1996. The effect of patch disturbance on stream invertebrate community structure: the influence of disturbance history. Oecologia, 108: 567-576.

DESCY, J. P. \& COSTE, M. 1989. Application d'un nouvel indice diatomique (indice CEE 88) au Réseau National de Bassin Rhône-MéditerrannéeCorse. Rapport A.F.B. Rhône-MéditerrannéeCorse, 86 pp.

EUROPEAN COMMITTEE FOR STANDARIZATION. 2004. Water quality - Guidance standard for the identification, enumeration and interpretation of benthic diatom samples from running waters. European Standard EN 14407. European Committee for Standardization, Brussels, $12 \mathrm{pp}$.

EUROPEAN UNION. 2000. Directive 2000/60/EC of the European Parliament and of the Council of 23 October 2000. Establishing a framework for community action in the field of water policy. Official Journal of the European Communities, 327: 1-72.

FLECKER, A. S. \& B. FEIFAREK. 1994. Disturbance and the temporal variability of invertebrate assemblages in two Andean streams. Freshwat. Biol., 31: 131-142.

GARCÍA-AVILÉS, J. 1990. Insectos acuáticos de Baleares (Odonata, Ephemeroptera, Heteroptera, Plecoptera y Coleoptera). Ph. D. Thesis. University Complutense of Madrid. 690 pp.

GASITH, A. \& V. H. RESH. 1999. Streams in Mediterranean climate regions: Abiotic influences and biotic responses to predictable seasonal events. Ann. Rev. Ecol. Syst., 30: 51-81.

GOMÀ, J. 2004. Les diatomees bentòniques de la Tordera: diversitat I utilització com a indicadors de la qualitat biològica de l'aigua. Diputación de Barcelona, 2004, pp. 37-45.

HUSTEDT, F. 1930. Die Kieselalgen Deutschlands, Österreichs und der Schweiz. In: L. Rabenhorst's Kryptogamen-Flora von Deutschlands, Österreichs und der Schweiz, 7(1). 920 pp.

HUSTEDT, F. 1959. Die Kieselalgen Deutschland, Österreich und der Schweiz. In: L. Rabenhorsts Kryptogamen-Flora von Deutchland, Österreich und der Schweiz, 7(2). 845 pp.

KELLY, M. G. \& B. A. WHITTON. 1995. The Trophic Diatom Index: A new index for monitoring eutrophication in rivers. J. Appl. Phycol., 7: 433-444.

KELLY, M. G., A. CAZAUBON, E. CORING, A. DELL'UOMO, L. ECTOR, B. GOLDSMITH, H. GUASCH, J. HÜRLIMANN, A. JARLMAN, B. KAWECKA, J. KWANDRANS, R. LAUGASTE, E. A. LINDSTROM, M. LEITAO, P. MARVAN, J. PADISAK, E. PIPP, J. PRYGIEL, E. ROTT, S. SABATER, H. VAN DAM \& J. VIZINET. 1998. Recommendations for the routine sampling of diatoms for water quality assessments in Europe. $J$, Appl. Phycol., 10: 215-224.

KRAMMER, K. 1997a. Die cymbelloiden Diatomeen. Eine Monographie der weltweit bekannten Taxa. Allgemeines und Encyonema Part. Teil 1. In: Bibliotheca Diatomologica, vol. 36. J. Krammer (eds.). Berlin-Stuttgart. 382 pp.

KRAMMER, K. 1997b. Die cymbelloiden Diatomeen. Eine Monographie der weltweit bekannten Taxa. Encyonema Part., Encyonopsis und Cymbellopsis. Teil 2. In: Bibliotheca Diatomologi$c a$, vol. 37. J. Krammer (eds.). Berlin- Stuttgart. 469 pp.

KRAMMER, K. 2002. Cymbella. In: Diatoms of Europe. Vol. 3. H. Lange-Bertalot (ed.). Koenigstein. A. R. G. Gantner Verlag K. G. 584 pp.

KRAMMER, K. \& H. LANGE-BERTALOT. 1985. Naviculaceae. Neue und wenig bekannte Taxa, neue Kombinationen und Synonyme sowie Bemerkungen zu einigen Gattungen. In: Bibliotheca Diatomologica, vol. 9. 230 pp.

KRAMMER, K. \& H. LANGE-BERTALOT. 1986. Bacillariophyceae 1 Teil: Naviculaceae. In: Sübwasserflora von Mitteleuropa. Band 2/1. Ettl, H., J. Gerloff, H. Heynig, \& D. Mollenhauer (eds). Gustav Fischer Verlag, Stuttgart-Jena. 876 pp.

KRAMMER, K. \& H. LANGE-BERTALOT. 1988. Bacillariophyceae 2 Teil: Bacillariaceae, Epithemiaceae, Surirellaceae. In: Sübwasserflora von Mitteleuropa. Band 2/2. Ettl, H., J. Gerloff, H. 
Heynig, \& D. Mollenhauer (eds). Gustav Fischer Verlag, Stuttgart-Jena. 596 pp

KRAMMER, K. \& H. LANGE-BERTALOT. 1991a. Bacillariophyceae 3 Teil: Centrales, Fragilariaceae, Eunotiaceae. In: Sübwasserflora von Mitteleuropa. Band 2/3. Ettl, H., J. Gerloff, H. Heynig, \& D. Mollenhauer (eds). Gustav Fischer Verlag, Stuttgart-Jena. 576 pp.

KRAMMER, K. \& H. LANGE-BERTALOT. 1991b. Bacillariophyceae 4 Teil: Achnanthaceae. In: Sübwasserflora von Mitteleuropa. Band 2/4. Ettl, H., J. Gerloff, H. Heynig, \& D. Mollenhauer (eds). Gustav Fischer Verlag, Stuttgart-Jena. 437 pp.

KRAMMER, K. \& H. LANGE-BERTALOT. 2000. $2^{\text {nd }}$ edition. Bacillariophyceae 3. Teil: Centrales, Fragilariaceae, Eunotiaceae. In: Sübwasserflora von Mitteleuropa. H. Ettl, J. Gerloff, H. Heynig \& D. Mollenhauer (Ed.), Spektrum Akademischer Verlag, Heidelberg \& Berlin, 2/3. 576 pp.

LAKE, P. S. 2000. Disturbance, patchiness, and diversity in streams. J. North Am. Benthol. Soc., 16: 221-238.

LAKE, P. S. 2003. Ecological effects of perturbation by drought in flowing waters. Freshwat. Biol., 48: 1161-1172.

LANGE-BERTALOT, H. 1993. 85 neue Taxa und über 100 weitere neu definierte Taxa ergänzend zur Süsswasserflora von Mitteleuropa. In: Bibliotheca Diatomologica. Vol. 27. J. Krammer (eds.). BerlinStuttgart. 454 pp.

LANGE-BERTALOT, H. 1999. Neue Kombinationen von Taxa aus Achnanthes (sensu lato). In: Iconographia Diatomologica. Lange-Bertalot, $\mathrm{H}$. (ed.). 6: 278-291.

LANGE-BERTALOT, H. 2001. Navicula sensu stricto. 10 Genera separated from Navicula sensu lato. Frustulia. In: Diatoms of Europe. Vol. 2. H. Lange-Bertalot. (ed.). A. R. G. Gantner Verlag K. G. 526 pp.

LANGE-BERTALOT, H. und K. KRAMMER. 1989. ACHNANTHES eine Monographie der Gattung. Mit definition der Gattung Cocconeis und Nachträgen zu den Naviculaceae. In: Bibliotheca Diatomologica, vol. 18. J. Krammer (eds.). BerlinStuttgart. Berlin. 393 pp.

LANGE-BERTALOT, H. \& G. MOSER. 1994. Brachysira. Monographie der Gattung. In: Biblioteca Diatomologica. Vol. 29. J. Cramer. (ed.). BerlinStuttgart. 212 pp.
LANGTON, P. \& J. CASAS. 1999. Changes in chironomid assemblage composition in two Mediterranean mountain streams over a period of extreme hydrological conditions. Hydrobiologia, 390: 37-49.

LECOINTE, C., M. COSTE \&, J. PRYGIEL. 1993. “«OMNIDIA» software for taxonomy, calculation of diatom indices and inventories management". Hydrobiologia, 269: 509-513.

LEIRA, M. \& S. SABATER. 2005. Diatom assemblages distribution in Catalan rivers, NE Spain, in relation to chemical and physiographical factors. Water Research, 39(1): 73-82.

LENOIR, A. \& M. COSTE. 1996. Development of a practical diatom index of overall water quality applicable to the French National Water Board Network. In: Use of Algae for Monitoring Rivers II. B. A. Whitton \& E. Rott (eds.): 29-43. Universitat Innsbruck, Innsbruck.

LLOBERA, M. \& A. FERRIOL. 1994. Seasonal fluctuations in the chemistry of limestone springs from the Tramuntana Mountain Range (Mallorca, Spain). Verh. Internat. Verein. Limnol., 25: 1445-1448.

LORENZEN, C. J. 1967. Determination of chlorophyll and phaeopigments: spectrophotometric equations. Limno. Oceanograph., 12: 342-346.

MARGALEF, R. 1951. Materiales para la hidrobiología de la Isla de Ibiza. Publicaciones del Instituto de Biología Aplicada, 8: 5-70.

MORAIS, M., P. PINTO, P. GUILHERME, J. ROSADO \& I. ANTUNES. 2004. Assessment of temporary streams: the robustness of metric and multimetric indices under different hydrological conditions. Hydrobiologia, 516: 229-249.

MOYÀ, G., A. FERRIOL \& M. LLOBERA. 1991. Chlorophyll contents in the freshwater vegetation of Serra de Tramuntana springs (Majorca, Spain). Verh. Internat. Verein. Limnol., 24: 2002-2006.

MOYÀ, G., BENNASAR, C. FRAU, L. GARCIA, M. GÓMEZ \& G. RAMÓN. 1993. Long term changes (after twelve years) in the composition of phytoplankton communities in the Gorg Blau reservoir (Majorca, Spain). Verh. Internat. Verein. Limnol., 25: 1257-1261.

PARDO, I. \& M. ALVÁREZ. 2006. Comparison of resource and consumer dynamics in Atlantic and Mediterranean streams. Limnetica, 25(1-2): 271-286.

PARDO, I., M. ALVAREZ, C. DELGADO, L. GARCÍA, P. LUCENA. 2007: Implementación de la DMA en Baleares: evaluación de la calidad ambiental de las masas de agua epicontinentales utilizando indicadores e índices biológicos. Tomo 
I: Torrentes (Informe Técnico). Universidad de Vigo. 302 pp.

PASSY, S. I. \& R. W. BODE. 2004. Diatom Model Affinity (DMA), a new index for water quality assessment. Hydrobiologia, 524: 241-251.

PERÁN, A., J. VELASCO \& A. MILLÁN. 1999. Life cycle and secondary production of Caenis luctuosa (Ephemeroptera) in a semiarid stream (Southeast Spain). Hydrobiologia, 400: 187-194.

POFF, N. L. \& J. V. WARD. 1989. Implications of streamflow variability and predictability for lotic community structure: a regional analysis of streamflow patterns. Can. J. Fish. Aquat. Sci., 46: $1805-1818$.

POFF, N. L. 1992. Why disturbances can be predictable: a perspective on the definition of disturbance in streams. J. North Am. Benthol. Soc., 11(1): 86-92.

PRYGIEL, J. \& M. COSTE. 1993: Utilisation des indices diatomiques pour la mesure de la qualité des eaux du bassin Artois-Picardie: bilan et perspectives. Annals of Limnology, 29(3-4): 255-267.

RENBERG, I. 1990. A procedure for preparing large sets of diatom slides from sediment cores. $\mathrm{J}$. $\mathrm{Pa}$ leolimnol., 4: 87-90.

RESH, V. H., A.V. BROWN, A. P. COVICH, M. E. GURTZ, H. W. LI, G. W.MINSHALL, S. R. REICE, A. L. SHELDON, J. B. WALLACE \& R. WISSMAR. 1988. The role of disturbance in stream ecology. J. North Am. Benthol. Soc., 7: 433-455.

ROMANÍ, A. M. \& S. SABATER. 1997. Metabolism recovery of a stromatolitic biofilm after drought in a Mediterranean stream. Arch. Hydrobiol., 140: 261-271.

SABATER, S. 1989. Encrusting algal assemblages in a Mediterranean river basin. Arch. Hydrobiol., 114: 555-573.

SABATER, F. \& J. ARMENGOL. 1986. Chemical characterization of the Ter river. Limnetica, 2: 75-84.

SABATER, S. \& F. SABATER. 1988. Diatom assemblages in the river Ter. Arch. Hydrobiolol.
111(3): 397-408.

SABATER, S., A. BUTTURINI, I. MUÑOZ, A. ROMANÍ, J. WRAY \& F. SABATER. 1998. Effects of removal of riparian vegetation on algae and heterotrophs in a Mediterranean stream. Journal of Aquatic Ecosystem Stress and Recovery, 6: 129-140.

STOUT, R. J. 1981. How abiotic factors affect the distribution of two species of tropical predaceous aquatic bugs (family: Naucoridae). Ecology, 62: 1 170-1 178.

STOUT, R. J. 1982. Effects of a harsh environment on the life history patterns of two species of tropical aquatic Hemiptera (Family: Naucoridae). Eco$\log y, 63: 75-83$.

STUDEMANN, D., P. LANDOLT, M. SARTORI, D. HEFTI \& I. TOMKA. 1992. Ephemeroptera. Sociêté entomologique Suisse. Switzerland. 175 pp.

TOWNS, D. R. 1985. Limnological characteristics of a South Australian intermittent stream, Brown Hill Creek. Australian Journal of Marine and Freshwater Research, 36: 821-837.

VAN DAM, H., MERTENS, A. \& J. SINKELDAM. 1994. A coded checklist and ecological indicator values of freshwater diatoms from The Netherlands. Netherlands Journal of Aquatic Ecology, 28: 117-133.

WERUM, M. \& H. LANGE-BERTALOT. 2004. Diatoms in springs from central Europe and elsewhere under the influence of hydrogeology and anthropogenic impacts. In: Iconografia Diatomologica, vol. 13. H. Lange-Bertalot (ed.). A. R. G. Garner Verlag K.G. 417 pp.

WILLIAMS, D. D. 1996. Environmental constrains in temporary freshwaters and their consequences for the insect fauna. J. North Am. Benthol. Soc., 15: 634-650.

WRONA, F. J., J. M. CULP \& R. W. DAVIES. 1982. Macroinvertebrate subsampling: a simplified apparatus and approach. Can. J. Fish. Aquat. Sci., 39: 1 051-1 054. 